\title{
Approaching a pedagogical model of prison education
}

\section{Aproximación a un modelo pedagógico de educación carcelaria}

\author{
ORTEGA-SANCHEZ, Edgar Ricardo ${ }^{*}$ \\ Centro de Investigación e Innovación para el Desarrollo Educativo (CIIDE) \\ Colegio de Estudios Científicos y Tecnológicos del Estado de Durango (CECyTED)
}

ID $1^{\text {st }}$ Author: Edgar Ricardo, Ortega-Sanchez / ORCID: 0000-0001-5802-373X; PUBLONS ID: 3062399, CVU CONACYT ID: 827389

DOI: $10.35429 / J E H .2019 .4 .3 .18 .25$

Received February 14, 2019; Accepted June 19, 2019

\begin{abstract}
The Colegio de Estudios Científicos y Tecnológicos del Estado de Durango (CECyTED), offers high school studies based on two pedagogic schemes, the first one is a technique formation, by different schools CECyTED; the second one, a Median High Education of Distance, denominated Educacion Media Superior a Distancia (EMSaD) a general high school that capacitates as Educational workers. They oppress in 71 schools that covers the majority part the state of Durango. Since 1996, attends students of prison centers, based on the schemes EMSaD with a schoolar modality, has at this day near of 700 students in the data base, and hundreds of students graduated in all the prison centers in the State of Durango. In a national level, this is the unique subsystem that provides this service and modality in the prison centers in an international level in Latin America, is the unique model with regular courses in the prison centers. By the way, the pedagogical model is not designed for this context, but it works with a model of students of common scholar context, it says outside of the prison. This project is a part of a series of different works and successful experiences shared for some years in different Prison Centers in the State of Durango. This emphasizes in the creation of a Dirección de Educación Carcelaria, this constituted a line that make the opportunity to recognize the pedagogical precepts, administrative and infrastructure needs of the prison. The objetive is to show a padagogic model to educate in confinement contexts. The method used in this work is action-research, and the contribution is the potentiation and the aplication of the model in México's jails and other countries.
\end{abstract}

Direction, Education, Prison, Pedagogical model

\section{Resumen}

El Colegio de Estudios Científicos y Tecnológicos del Estado de Durango (CECyTED), ofrece estudios de bachillerato basados en dos esquemas pedagógicos, el primero es una formación técnica, por diferentes colegios CECyTED; la segunda, una Mediana de Educación Superior de Distancia, denomina Educación Superior a Distancia (EMSaD) una escuela secundaria general que capacita como trabajadoras educativas. Oprimen en 71 escuelas que cubren la mayor parte del estado de Durango. Desde 1996, asiste a estudiantes de centros penitenciarios, basados en los esquemas EMSaD con una modalidad escolar, tiene en este día cerca de 700 estudiantes en la base de datos, y cientos de estudiantes se graduaron en todos los centros penitenciarios en el estado de Durango. A nivel nacional, este es el subsistema único que proporciona este servicio y modalidad en los centros penitenciarios a nivel internacional en América Latina, es el modelo único con cursos regulares en los centros penitenciarios. Por cierto, el modelo pedagógico no está diseñado para este contexto, pero funciona con un modelo de estudiantes de contexto académico común, dice fuera de la prisión. Este proyecto forma parte de una serie de obras diferentes $y$ experiencias exitosas compartidas desde hace algunos años en diferentes Centros Penitenciarios del Estado de Durango. Esto pone de relieve en la creación de una Dirección de Educación Carcelaria, que constituyó una línea que aprovecha la oportunidad de reconocer los preceptos pedagógicos, las necesidades administrativas y de infraestructura de la prisión. El objetivo es mostrar un modelo padagogic para educar en contextos de confinamiento. El método utilizado en este trabajo es la investigación de acción, y la contribución es la potenciación y la aplicación del modelo en las cárceles de México y otros países.

Dirección, Educación, Cárcel, Modelo Pedagógico

Citation: ORTEGA-SANCHEZ, Edgar Ricardo. Approaching a pedagogical model of prison education. Journal-Economic History. 2019. 3-4: 18-25.

\footnotetext{
* Correspondence to Author (email: erosgi792@gmail.com)

$\uparrow$ Researcher contributing as first author
} 


\section{Introduction}

The Colleges of Scientific and Technological Studies (CECyTEs) in the State of Durango were born in 1993, through the Technological Baccalaureate modality, offering the first services in the CECyTED 01 Campus, in Las Nieves, Villa Ocampo. Throughout these years, coverage has been extended, so that 71 schools are currently in the State. Legally formalized in 1997. In the same year, the project began to provide distance higher secondary education service in the state, which was offered by the General Baccalaureate (BAGEs) and by the socalled Higher Middle Distance Education (EMSaD). Previously, in 1995, agreements were signed with the authorities of the Social Readaptation Center (CERESO No. 1) of the State, located in the Capital City to teach in this Penitentiary Center. Gradually, collaboration agreements were signed with the other prisons of the State: in 1997 with the Federal Center for Social Readaptation (CEFERESO) of Guadalupe Victoria; in 2009 with the District Center for Social Reinsertion (CEDIRESO No. 1) of El Salto, Pueblo Nuevo, Dgo .; and in 2011 at the District Center for Social Reinsertion (CEDIRESO No. 2) of Santiago Papasquiaro, Dgo. The Specialized Centers for Readaptation and Treatment for Minor Offenders (CERTMI) of Gómez Palacio and the City of Durango are also attended. From all this, we start to create this project under a main problem: the CECyTED and the Mexican Educational System lack a pedagogical-administrative model of care for prison centers. This work contains the proposal for the implementation of its own pedagogical model for the Prisons of Higher Secondary Education, and particularly focuses on the development of teaching and learning strategies, adapted teaching and curricular materials, as well as the consideration of an education located that optimize the educational service in confinement contexts. The proposed model has been called CEAPlaMSiCC, whose meaning refers to the particular needs of penitentiary education schemes: Teacher and managerial training; Adapted evaluation; Curricular adaptations; Adapted planning; Adapted curriculum and teaching materials; Situations and Contingencies for the Jail. Under this model, specific elements are raised, which have been considered to be projected from intervention strategies under the methodology of action research.
From all of the above it follows that the contributions of the work are clear, insofar as they contribute to the formalization of a pedagogical model for the prison. Similarly, contributions in education and human rights for the attention of marginalized groups are also reflected in this research.

Finally, with regard to theoretical contributions, important elements are conglomerated, based on classical authors, educators and contemporary pedagogues, whose theories focus on the treatment of lines and perspectives aimed at inclusive work and attention to diversity, but also specifically on Persons Deprived of Liberty (PPL).

\section{Theoretical discussion}

\section{Prison education}

Recent pedagogical practices, at almost all educational levels, have been restructured and "modernized" in the theoretical sense. The teachers of now, are linked more (in a compulsory or voluntary way) with a pedagogy of constructivist tendency than traditional, to mention only two of the predominant and best known models.

The conceptualization of teaching adapts to new theoretical trends. Authors, classics, educators and contemporary pedagogues have approached diverse and plural elements about teaching, having different constructions in models, trends and perspectives as varied as authors on it exist. Namely: Pérez and Gimeno (1996, p. 79) affirm that "the teaching starts from different theoretical approaches that assume it as a task in the field of knowledge and action, and through which the practice that has to Do the teacher. The same author proposes three theoretical perspectives to define teaching ("cultural transmission"; "promotion of natural development" and "skills training"), through which he proposes his definition of teaching:

A process that facilitates the permanent transformation of students' thoughts, attitudes and behaviors, provoking the contrast of their more or less spontaneous acquisitions in their daily lives with the proposals of the scientific, artistic and speculative disciplines, stimulating their experimentation in the reality (Pérez and Gimeno, 1996, p. 80). 
There are other authors and perspectives on teaching and its models, definitions and proposals for action, which assume it as a task in the field of knowledge and action, and through which, the practice to be done by the teacher takes shape. (Pérez and Gimeno, 1996, p. 401: academic perspective, technical perspective, practical perspective and reflection in practice for social reconstruction). Santoianni and Striano (2000, p. 75: constructivist, contextualist and culturalist heuristic lines), among others.

Within the Encierro Centers, cultural codes and symbolic artifacts, both for communication, teaching and learning vary from other regular schools; In this sense, the "heuristic lines" of Santoianni and Striano define teaching as an activity that is subject to the plurality and ecological dependence of human action ... In this environment (prison-school), internal students, Private Persons de la Libertad (PPL) from 2018 configure their actions in very specific and specific ways, and that way it has to be teaching so that it can be effective in this complex educational circle. The teaching strategies to be followed must be consistent with these very special and unique actions and, with this, make clear the constitutional requirements of attention and Human Rights to the PPLs specifically, our Magna Carta (Art. 18, p. 25) to the letter refers: The governments of the Federation and those of the States will organize the Criminal System, in their respective jurisdictions, on the basis of work, training for it and education as means for the social retraining of the offender. Women will confuse their sentences in places separate from those destined for men for this purpose.

For its part, the Constitution of the State of Durango, (Art. 9, p. 18) on education in prisons argues:

The Penitentiary System in the State of Durango will be organized on the basis of work, training for it, education, health and sport as means to achieve the reintegration of the sentenced to society and ensure that he does not commit a crime again, observing the benefits that the Law provides for.

However, some authors and specialists on the subject are not at all compliant with the laws and theories of Human Rights in their penitentiary practice, except in regard to education.
For example, Kouyoumdjian L. and Poblet, M., (2010, p. 7) have a theoretical perspective around which they argue that: "education as a therapeutic treatment is based on the speeches of" re ": reintegration, social rehabilitation, social reintegration, reeducation, resocialization, among others ... In this way education is disregarded as a right that enables human development." "This grotesque interpretation of education does not reflect the prisoner as a human being at all" (Daroqui, 2010, p. 58).

In our country, there are strong criticisms of the educational and prison systems, among which corruption within prisons and the palliative situation of school institutions stand out as "mere nurseries" that help the prison administration with activities that keep the PPL, but that little contribute to their academic and personal growth.

Higher Middle Education (EMS): 2017 Educational Model and New Mexican School (NEM)

EMS was created in the late nineteenth century in our country and has been growing very slowly; by the beginning of the 20th century, coverage was scarce, but it was detonated from the 70s, and reached a boom in attention in the 90s; Today, 3 out of every four students able to attend it are in a preparatory school, and according to the 2016 Educational Model (p. 8), for the 2021-2022 school year the coverage will be one hundred percent.

However, this level continues to have great challenges, especially those that have to do with quality, equity and the decrease in school drop-out, so that a care model has been proposed that minimizes the gap in these priority areas: the 2016 educational model, which seeks:

... Realize the right to education for all, based on the principles that support inclusive education, postulates the elimination of barriers that prevent learning and participation for all students, with special emphasis on those who have conditions of vulnerability (SEP, 2016, p. 15). 
This approach can be interpreted as an objective of pedagogical attention and in the case of this project it should be clear that students deprived of liberty, teachers of the Encierro Centers and other agents working in them are a priority of attention, over all if one considers that the same model has the following features and characteristics:

\section{Humanistic approach.}

\section{The school downtown.}

3. Prepared and trained teachers.

4. To break down barriers that make learning difficult, regardless of the conditions of the students: origin, gender, socioeconomic status, cultural diversity, geographic and social contexts, including those in conditions of disability and multiple situations of vulnerability (here enter our students and teachers).

5. An effective governance of the education system.

6. Complete, timely and consistent educational materials.

7. A flexible curricular approach based on the overcoming of contents and on the focus of key learning (integrating educational philosophy, capacities and advances in cognitive development, intelligence and learning.

8. A flexible approach, through the application of the Common Curricular Framework (MCC): generic and disciplinary competencies as "life" competencies.

9. The concept of "professional training" is addressed.

10. Finally, an education in and for Human Rights is sought, in which the objective is the integral development and adaptation of the curriculum, so that it responds to the needs of any context, through the expansion and flexibility of educational modalities for the disadvantaged population (rural, indigenous, with disabilities) (SEP, 2016) ... and we add, the prison population.
On the other hand, the postulates of the New Mexican School (2019), pose for the EMS the following outstanding elements: 6 guiding axes have been projected on which the operation of the EMS has been established. Broadly speaking, it is proposed to revalue the teaching function and link learning directly with the students' social environment, but above all, it is intended to improve the work situations of those in precarious conditions (Arroyo, 2019), which is the PPL case.

All these features legitimize the need for attention and the creation of a model of care for education in prisons, since policies of inclusive education and coverage require it, if the consideration is made that in our country there are more than 200,000 PPL in centers Prisons: 211,000 in October 2016, of which more than $64 \%$ are potential enrollment to study Higher Secondary Education and are neglected (INEGI, 2017).

\section{Pedagogical models}

In relation to teaching and learning, there are as many lines, authors and models as authors on the subject are consulted. Among the most recent works in this regard, is the family of learning models, which starts from a specific classification, emphasizing the definitions of teaching and the role of the teacher in each perspective. Joyce (2000) defines a teaching model as "a description of a learning environment, including our behaviors as teachers when we use that model"

For his part Ramírez (2012, p. 2) conceives a model as "something desirable, a must be, a representation of an element of reality, the expression of the most important elements of what you want to show". In terms of education, Ramírez herself emphasizes that an educational model has the desirable components and elements that integrate the meaning and orientation of what you want to schematize. Thus, each educational, business or any other institution builds its own model according to the guidelines and objectives it intends to achieve. In the case of educational institutions, the socalled "teaching models" are also proposed. A teaching model is "A structured plan that can be used to set up a curriculum (long-term course of study), to design teaching materials and to guide classroom teaching (Joyce and Weil, in Ramírez, 2012, p. 3). 
"Teaching models are prescriptive strategies to meet particular teaching goals. They are prescriptive because the responsibilities of the teacher during the planning, implementation and evaluation stage they are clearly defined".

Eggen and Kauchak, 1999, in Ramírez (2012, p. 3). Ramírez herself (2013, p. 4): “The model is specifically designed to achieve a particular objective and determine a large part of the facilitator's actions.

A teaching model is a kind of model to teach." Among the teaching models there are various classifications: The model or social family: emphasizes the relationship between the individual and other people; peer learning and study of values.

The model or personal family: underlines the processes by which the individual builds his unique reality; non-directive education and life preparation.

The information processing model: the construction of knowledge is the central axis. Work with metacognitive thinking skills and deep analysis of various kinds. The model or behavioral family: aims to change the visible behavior of the subject, rather than the latent psychological structure and unobservable behavior; its main features, learning to learn, direct instruction and simulations. Joyce, Weil and Calhoum, 2000, in Ramírez (2012). After showing this analysis of concepts, models, approaches, perspectives and heuristic lines on teaching, it is necessary to recognize those who have a close relationship with the forms of teaching in Prisons should focus on the learning situations and administration of the centers themselves and of the school institutions that are inside.

There is no model that suits, so it is necessary to build your own. In this work, the model is clearly referenced, based on action research, from the perspective of reflective and creative practice to produce changes that improve teaching and learning in prison centers.

The theoretical schemes of the proposed pedagogical model are detailed below. It should be clarified that what is shown here is an approximation and that the specific lines and strategies are in operation at the date of production of this document.

\section{CEAPlaMSiC pedagogical model}

Teacher and board training: references and theoretical information on prison and educational systems; Higher education plans and curricula; curricular adaptations and cognitive nodes; own planning and evaluation for our schools; teaching-learning strategies; issues about values and teaching ethics, psychological support for teachers and interns, resilience, among others.

Adapted assessment: own school control; focused and adapted evaluation system; design of focused exams and other evaluation instruments, such as rubrics, checklists, observation guides, among others.

Curricular adaptations: significant and non-significant adaptations; cognitive nodes and 2016 adapted educational model.

Adapted planning: own planning format, competencies, competence units, objectives and purposes for teachers and internal students (PPL).

Adapted curricular and teaching materials: textbooks, manuals and booklets for students deprived of liberty.

Situations and Contingencies for the Prison: consideration of contingencies in the field of prison education; development of contingent plans, which considers the most common events, such as: absences due to transfers, family visits, illnesses, student work, releases, among others (development of matrices and contingent plans).

\section{Model Implementation}

Problems have been grouped by scope; the areas of opportunity are specified in each. The actions taken from each element are planned, considering the specific objectives and goals, those responsible, the resources, the times and the forms of monitoring and evaluation. Likewise, some instruments, forms and types of evaluation will proceed, which will have to be specified. by the corresponding areas or responsible. 


\section{Actions by priority in the pedagogical- educational field}

It refers to school and aulic processes, as well as the elements that compose them: students, teachers, managers in general; teaching process learning in particular.

\section{Problems generated in the diagnosis:}

1. Considerations have not been made that our students are in vulnerable and disadvantaged situations, with respect to regular school students ... (in most cases): they arrive at the CECyTED classrooms with very low achievement, since close to 95\% of them attend their basic level (primary and secondary) at the State Institute for Adult Education (IDEA). There are cases of students who in two years attend the two previous levels (primary and secondary) and arrive at the high school without knowing how to read or write (there are senior citizens, who are 50 years old or older without attending school).

2. There is no pedagogical or didactic model that has been developed for the facilities that are held in the Correctional Centers; therefore, there are no specific attention schemes, such as: planning formats, elaboration of didactic sequences, application of evaluation instruments, use of specific textbooks; much less has been thought of developing a list of skills or learning for prison schools.

3. There is no teacher training scheme, nor directive before or after admission to the prison educational service.

4. Poor results have been obtained in the National Plan for Learning Assessment (PLANEA) test.

The following table summarizes the main and complementary actions, according to the problems found:

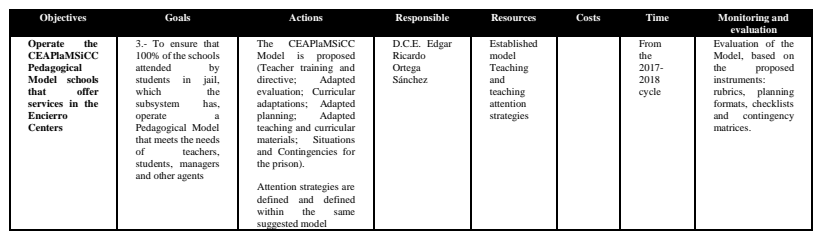

Table 1 Specific actions proposed by the CEAPlaMSiCC model

Source: self-made

\section{Methodology}

Action research is the process of reflection by which, in a given area, where it is desired to improve practice or personal understanding, the practicing professional conducts a study; First, to clearly define the problem; second, to specify an action plan. An evaluation is then undertaken to verify and establish the effectiveness of the action taken. Finally, participants reflect, explain progress and communicate these results to the community of action researchers. Action research is a self-reflective scientific study of professionals to improve practice.

This form of inquiry transports the world of reflection, because alternatives are sought to change a problem and bring us closer to interacting directly with the social environment and with the same individual who forms it, turning their practice into an immediate meditation task, then analyze why the transformation is a change with various satisfactions of relevance to the human being.

Under these ideas, the projection of this model has been constituted, which is based on the Kemmis scheme:

A form of self-reflective inquiry, carried out by those who participate (teachers, students, or directors, for example) in social situations (including educational ones) to improve the rationality and justice of: a) their own educational social practices; b) your understanding of them; and c) the situations and institutions in which these practices are carried out (classrooms, schools, for example) (Kemmis, 1984, in Latorre, 2003, p. 25).

Action research is made up of methodological criteria, concepts and principles that generally assume an emancipatorytransformative position, around social problems, but mainly educational ones. 
Among the research-action models that have been postulated, this work was based on the model developed by Kolb, Karr and Kemmis (1988, in Latorre, 2003, p. 33), who define the model as "spirals in action", in reference that there is always a transformative action.

What this model entails is the successful implementation of an action plan, to subsequently execute it as planned; the action is immediately observed and evidence is collected to evaluate the action.

Finally, we reflect on the action carried out, this can lead to the reconstruction of the meaning of the social situation and provide the basis for another new planning and continue another cycle (Latorre, 2003, p. 33).

This research was based on the Kemmis model, 1989, (in Rodríguez, et. Al 1999, p. 54), whose phases are determined more directly and concatenated with each other naturally; in the teaching environment in the Prison Centers, significant and simple strategies that impact on teachers and students must be specified, so as to improve the pedagogical and didactic aspect of the model with which they work in these centers and optimize teaching in this context.

This paper follows up on this proposal (from Kemmis), first, taking into account that it is designed exclusively to apply to teaching and learning, the main object of the proposal's approach; second, considering the flexibility that it allows in a prison context, making the consideration that the adjustments always depend on the administrative and academic facts and on variations of various kinds that occur frequently in the Penitentiary Center.

Thus, the CEAPlaMSiCC model is a potential theoretical-practical construction, although at the time of formalization of this work, textbooks for the prison context have been completed, which are part of one of the elements of the model ( Teaching and curriculum materials for jail). Specifically, the books of Reading and Writing Workshop II and Mathematics II have been prepared.

\section{Conclusions}

Continuous improvement as teachers makes students face individual and collective work and commitment schemes; With works like this, the ethical schemes of the students of prison centers are modified, which are more interested, more committed and regular in their school activities, although they have, as they say, other "more important things to do".

By optimizing teaching, the benefits offered to other aspects such as educational lag also come to light; The disposition and work of the teacher have contributed to the disappearance of the lag in state prisons, since $100 \%$ of the students who are able to enter this educational level are served. The concept of "social reintegration" is thus committed, working on aspects of an institutional nature and human rights, among others. These and other elements are addressed in this work.

This is expected to crystallize an educational intervention line that strengthens the Duranguense Education System, CECyTED and the National Education System, and especially the comprehensive care of almost 211,000 people deprived of liberty in Mexico.

\section{References}

Aguilar, J. y Block, A. (2006). Planeación escolar y formulación de proyectos $\left(3^{\mathrm{a}}\right.$. Ed.). México: Trillas.

Alvarado, O. (2005). Gestión de Proyectos Educativos. Lineamientos Metodológicos. Perú: Centro de Producción de Fondo Editorial.

Amaya Editores Constitución Política del Estado Libre y Soberano de Durango (2013). Art. XIII. México: Amaya Editores

Ander-Egg, E., Aguilar, M. (1997). Cómo elaborar un Proyecto. (13 ${ }^{\mathrm{a}}$. Ed.). Argentina: Colección política, servicios y trabajo social.

Arroyo, J. (2019). Líneas de política pública para la Educación Media Superior. México: SEP. Recuperado de

Constitución Política de los Estados Unidos Mexicanos (2013). Art. XVIII. México: Autor 
Daroqui, M. (2005). La cárcel por dentro... estos te roban todo. En grupo de trabajo: control, legitimidad y seguridad Ciudadana. XXV Congreso de la Asociación Latinoamericana de Sociología, Brasil.

Foucault, M. (2009). Vigilar y castigar. Nacimiento de la prisión. México: Siglo XXI.

INEGI (2017). ENPOL 2017. México: Autor. Consultado en www.INEGI.org.mx

ITESM (2012). Diseño de Proyectos educativos. Metodología de Trabajo en los Proyectos. Recuperado de www.ruv.itesm.mx

Joyce, B. (2000). Models of teaching. USA: Allyn and Bacon

Kaufman, R. (2006). Planificación de Sistemas Educativos. México: Trillas.

Kouyoumdjian, L. y Poblet, M. (2010). Un punto de fuga. La educación en cárceles, aportes desde el trabajo social. En Margen, Revista de Trabajo Social y Ciencias Sociales. No. 58.

Latorre, A. (2003). La investigación-acción. Conocer y cambiar la práctica educativa. Barcelona, España: Graó.

Llamas L. (2012). ¿Cuánto nos cuesta un preso? Recuperado de: http://www.sinembargo.mx/opinion/10-092012/9421

Melossi, D. y Pavarini M. (2010). Cárcel y fábrica. Los orígenes del Sistema Penitenciario (siglos XVI y XIX). México. Siglo XXI.

Ortega, E. (2014). Estrategias para optimizar la enseñanza en los planteles EMSaD- CECyTED en los Centros Distritales de Reinserción Social del Estado de Durango. Tesis sin publicar. México: IUNAES

Pérez, A. y Gimeno, J. (1996). Comprender y transformar la enseñanza. España: Morata.

Ramírez, M. (2012). Modelos y estrategias de enseñanza para ambientes innovadores. México: ITESM. Recuperado de https://books.google.com.mx/books?id=0HFlD wAAQBAJ\&pg=PT9\&lpg=PT9\&dq=
Rodríguez, G., Gil J. y García E. (1999). Metodología de la Investigación cualitativa. Granada, España, Aljibe.

Santoianni, F. y. Strianno (2006). Modelos teóricos y metodológicos de la enseñanza. México: Siglo XXI.

Scarfó, F. (2003). El derecho a la educación en las cárceles como garantía de la Educación en Derechos Humanos. Revista IIDH, No. 36, edición especial sobre educación en derechos humanos. Costa Rica.

SEMS (2008). Reforma Integral de la Educación Media Superior en México. México: Autor

SEP (2016). El Modelo Educativo 2016. El planteamiento pedagógico de la Reforma Educativa. México: Autor.

Stenhouse, L. (1987). La investigación como base de la enseñanza. Madrid, España: Morata. 